\title{
The Freedom Charter @ 60: Rethinking its democratic qualities
}

\author{
Raymond Suttner*
}

\begin{abstract}
The Freedom Charter is revisited as a democratic document with specific qualities deriving from the South African history of oppression. The object is not to advance the document as having obviously worthy qualities or for any partisan purpose. The aim is to unpack the meanings of its democratic qualities, found in the repeated reference to "the people" and especially in the clause entitled "The People Shall Govern!" The paper recognises that this clause may have been equated with universal suffrage at the time of its adoption in 1955, but the experiences in the 1980s "popular power" period amplified its meaning to incorporate the notion of popular, direct democracy. This coincides with the original meaning of the word "democracy", as propounded by Aristotle. At the same time it is argued that popular democracy is not necessarily incompatible with representative democracy, especially if one breathes an emancipatory meaning into the notion of "representation".
\end{abstract}

Key words: Freedom Charter; "the people"; representation; popular; 1950s; 1980s; emancipation.

\section{Opsomming}

Die Vryheidsmanifes word opnuut besoek as 'n demokratiese dokument met eiesoortige eienskappe wat vanuit Suid-Afrika se geskiedenis van verdrukking voortspruit. Dit is nie daarop gemik om die dokument te loof as iets wat vanselfsprekend waarde dra nie, ook nie om bepaalde belange te bevorder nie. Die doel is om die betekenis van die dokument se demokratiese karaktertrekke te ontrafel, naamlik in die herhaalde verwysing na "the people" (die mense) en veral in

\footnotetext{
* Raymond Suttner, based in Johannesburg, is a professor attached part-time to Rhodes University. His most recent work is Recovering Democracy in South Africa, published by Jacana Media in 2015. His current research relates to historical, political and gender studies. Email: raymond@suttner.co.za I am indebted to Arianna Lissoni, Nomboniso Gasa, Michael Neocosmos and anonymous readers for comments on this article, which helped to tighten the arguments presented.
}

How to cite this article:

R. Suttner, "The Freedom Charter @ 60: Rethinking its democratic qualities", Historia 60, 2, November 2015, pp 1-23. http://dx.doi.org/10.17159/2309-8392/2015/v60n2a1

Copyright:

(C) 2015. The Author(s). Published under a Creative Commons Attribution License. 
die klousule getiteld “The People Shall Govern!” (Die mense sal regeer!). Die artikel neem kennis van die feit dat dié klousule ten tyde van sy aanvaarding in 1955 gelyk gestel is aan algemene stemreg. Die belewenis van die 1980's, wat gekenmerk is deur 'n tydperk wat bekend gestaan het as "popular power" (populêre mag), het egter die klousule se betekenis verskerp en dit verbreed om die begrip van 'n populêre, direkte demokrasie in te sluit. Terselfdertyd word daar aangevoer dat populêre demokrasie nie noodwendig strydig is met verteenwoordigende demokrasie nie, veral nie as mens ' $n$ bevrydende betekenis by die begrip "verteenwoordiging" inweef nie.

Sleutelwoorde: Vryheidsmanifes; “die mense”; verteenwoordiging; populêr; 1950's; 1980's; bevryding.

\section{Introduction: The status and meanings of the Freedom Charter are not obvious}

In discussing the Freedom Charter today, even though it has existed and enjoyed a revered status amongst many people for 60 years, it is important that we do not treat its significance as being obvious. For there to be democratic debate one cannot treat most things as obviously desirable and necessary (or undesirable and unnecessary). Indeed the issues which may need to be debated around the Charter are not the same today as in 1955 or in the 1980s. The way one considers the Charter need not be restricted to unpacking the meanings of specific claims around each clause or a limited range of contentious clauses. It may also be useful to relate the Charter to understandings of the conceivable meanings of democracy and freedom as continually changing and potentially developing concepts. ${ }^{1}$

The Charter is both a universal document by virtue of some of the rights it demands, claimed in many parts of the world, as well as being very specifically contextual, deriving from the process through which it was created, incorporating the aspirations of people living in conditions peculiar to South Africa of the time that it was adopted.

The Charter has always been a contested document. It has been contested by the government under apartheid, by sections of the left, some but by no means all liberals, ${ }^{2}$ Africanists and later by adherents of black consciousness. The different ideological interpretations will not be "resolved" by one or other interpretative skill, which can then clearly uncover the Freedom Charter's "real" meaning. No person or organisation can give an authoritative and final meaning to the Freedom Charter. It needs to be understood within the conditions in which we find ourselves. What South

\footnotetext{
${ }^{1}$ A. Arblaster, Democracy, 3rd ed. (Open University Press, Buckingham, 2002), pp 3-11; J. Hoffman, Gender and Sovereignty, Feminism, the State and International Relations, (Palgrave, Houndmills, Basingstoke, 2001), pp 23, 25; J. Hoffman, John Gray and the Problem of Utopia (University of Wales Press, Cardiff, 2009), pp 176-179 and 186-187.

2 D. Everatt, The Origins of Non-Racialism: White Opposition to Apartheid in the 1950s, (Wits University Press, Johannesburg, 2010), pp 191-194; R. Suttner, The Freedom Charter - The People's Charter in the Nineteen Eighties, T.B. Davie Memorial Lecture (University of Cape Town, Cape Town, 1984), pp 20-21.
} 
Africa's distinguished theologian, Albert Nolan, says of religious texts is applicable here. The gospel is not meant to be interpreted by the letter, he argues, but its spirit must be carried through with due regard to changing contexts. ${ }^{3}$

In interpreting the Freedom Charter we can argue that it has a broad liberatory and emancipatory meaning. But we cannot say that there is only one meaning that attaches to some or possibly all of its clauses, or even that its main thrust is uncontested. The Freedom Charter arose in a specific moment in history and if it is to exist in a meaningful way, if it is to be a living document as part of distinct moments in time, it has to be recognised that the meaning to be given to the document may change. Equally, each one of us who interprets the Charter, may, as we imagine broader possibilities for the realisation of freedom, change our understandings of its potential scope and character.

\section{The Charter as a text}

The Charter was not written with the precision necessary in preparing a constitution. It has an "untidiness" in its formulations, arising from its combining various qualities. It was in the first place a reaction of ordinary people to their conditions of oppression. Their experiences were recorded with very specific demands, reflecting the peculiarities of apartheid domination. Where a specific form of oppression was experienced this would be listed and what was understood to be a remedy would be advanced, and very often both the demand and the remedies may have been peculiar to the conditions prevailing in South Africa at that particular time. ${ }^{4}$

These demands are joined with broad claims for what are more or less universal rights found in other human rights documents.

The "untidiness" may also be found in inconsistent use of terminology in the text itself. For example, the word "national" is used to refer to the people as a whole or having the scope of the country as a whole but also in the sense of what is called "national groups" which may be taken to mean racial or ethnic groups. ${ }^{5}$ This terminology may have been influenced by Soviet writing on nationalities, favoured by one of the leading historians and theorists of the time, Lionel Forman and derived

\footnotetext{
${ }^{3}$ A. Nolan, God in South Africa (David Philip, Cape Town, 1988), p 8.

${ }^{4}$ The process of collection is recorded in Suttner, The Freedom Charter, pp 4-12; R. Suttner and J. Cronin, 30 Years of the Freedom Charter (Ravan Press, Johannesburg, 1986), pp 4-110; R. Suttner and J. Cronin, 50 Years of the Freedom Charter (UNISA Press, Pretoria, 2006), pp 4110; I. Vadi, The Congress of the People and the Freedom Charter: A People's History (Jacana Media, Auckland Park, Johannesburg, 2015), pp 63-131; D. Everatt, "The Freedom Charter in Historical Perspective", in N. Steytler (ed.), The Freedom Charter and beyond: Founding Principles for a Democratic Legal Order (Wyvern Publications, Cape Town, 1991), pp 21-43. ${ }^{5}$ Suttner, The Freedom Charter, pp 17-18.
} 
inter alia from the writings of Soviet theorist, I.I. Potekhin. ${ }^{6}$ Incidentally, similar terminology is found in ANC discussion of the Freedom Charter ${ }^{7}$ and seems to have persisted into the 1980s in minutes of meetings where the "scourge of tribalism" was discussed and "nationalities" was advanced as an alternative word. ${ }^{8}$

\section{The Freedom Charter and democracy}

In focusing this paper on the democratic character of the Charter, features that are central to its political vision, its popular orientation and its emancipatory spirit, are highlighted.

In its opening words, phrased as a declaration, the Charter embraces a claim to popular sovereignty and democratic rule, made in the name of the people of South Africa. It immediately attacks the legitimacy of apartheid South Africa and simultaneously calls for a society, shared by all:

We the people of South Africa, declare for all our country and the world to know:

That South Africa belongs to all who live in it, black and white, and that no government can justly claim authority unless it is based on the will of all the people;

....

And therefore, we, the people of South Africa, black and white together equals, countrymen and brothers adopt this Freedom Charter.

That statement immediately raises the question whether such authority, vested in any body of state, even an elected one, is irrevocable. It may be a statement that has come back to haunt post-apartheid governments whenever they act in a manner that is perceived to be anti-popular or anti-democratic. Legitimacy, it will be argued below, is not something that is given once and for all but has to be earned and reearned, even possibly while enjoying an electoral mandate. If representatives are elected on one basis but perform in a manner that contradicts popular aspirations can their legitimacy not be impugned in terms of the very Freedom Charter that they claim to advance?

\footnotetext{
${ }^{6}$ L. Forman, A Trumpet from the Rooftops: Selected Writings, edited by S. Forman and A. Odendaal (Zed Books, London, 1992), pp 171-216.

${ }^{7}$ ANC, "First National Consultative Conference: The Freedom Charter Revolutionary Programme of the ANC", 1969, at http://www.anc.org.za/show.php?id=150, accessed 31 July 2015.

8 "Document 104: "Decisions of the ANC National Executive Committee, Luanda, 2-5 December 1981", in G.M. Gerhart and C.L. Glaser, From Protest to Challenge, A Documentary History of African Politics in South Africa, 1882-1990, Volume 6, Challenge and Victory, 19801990 (Indiana University Press, Bloomington, 2010), p 507.
} 


\section{“The People Shall Govern!"}

Democracy is needed for transformation but is a value in its own right. The first clause is clearly the starting point for any consideration of the democratic, liberatory and popular vision of the Charter. One cannot sidestep the question of democracy as if one can achieve transformatory goals without addressing democratic issues. At the same time, democracy is not merely of instrumental significance, seen purely as a means to achieve social and economic goals. It must be defended in its own right.

The clause declaring: “The People Shall Govern!” is at once simple and complex. Its meaning is not obvious and in the decades that followed the adoption of the Freedom Charter it may have come to be understood in new ways, augmenting and expanding the interpretations prevalent in 1955 (see below). ${ }^{9}$ This resulted less from the flourishing of debates than from struggles on the ground in the 1980s, what is called "mass creativity" in radical textbooks. In other words, the driving force for enhanced notions of democratic expression was not interpretative skill, though interpretation would be important, but that things had happened, that there were popular initiatives in the years that followed that amplified the potential ways the Charter could be understood.

\section{Who are "the people"?}

One is immediately struck in reading the Charter by how it is suffused with references to "the people". What characterises the Charter may be its broad popular character, but our understanding of the words "the people" and "popular" remain open to debate.

Denial of human rights always entails a fracturing of human personalities, injuries to human beings, denial of their humanity and their quality as persons. The claim to speak as "We, the people of South Africa ..." was a claim to human dignity and full personhood, to recover what had been splintered by apartheid oppression.

\footnotetext{
${ }^{9}$ While every leader of the ANC and allied Congresses stressed universal suffrage, potential elaborations on the meanings of this clause were not explored at the Congress of the People. See "Document 15: Police Record of the Congress of the People, Kliptown, Johannesburg, June 25-26 1955", in T.G. Karis and G.M. Gerhart, From Protest to Challenge, Volume 3, Challenge and Violence, 1953-1964, Revised edition by G.M. Gerhart (Jacana Media, Auckland Park, Johannesburg, 2013), pp 303-322, especially at pp 310-311. While Rusty Bernstein explains that the intention was that the clauses would be debated, police intervention cut into the duration of proceedings and there was no debate, simply an introduction of clauses and adoption. See R. Bernstein, Memory against Forgetting (Viking Penguin, London, 1999), p 158. Not much more was done in terms of interpretation in the years that followed. It should be recalled that most leaders were restricted or involved as accused in the Treason Trial of 1956-1961. Writing on the Charter, from within the Congress Alliance was limited. Insofar as there was contestation or debate it related mainly to the economic clauses and that continued to be the case in subsequent years.
} 
Looking back to 1955 one cannot but admire the boldness and audacity of a document created at the height of apartheid, daring to speak as "We, the people of South Africa" and "declaring", not simply advancing an idea, "for all our country and the world to know", that "South Africa belongs to all who live in it, black and white". Furthermore, it directly challenged the claim of the government of the time to continue to rule when it said, "no government can justly claim authority unless it is based on the will of the people".

To speak as "The People of South Africa" was also related to the notion of universal adult suffrage, adulthood being important in a society where black adults, but especially Africans were infantilised, spoken of as "boys" and "girls".

But the concept of "the people", while used in a positive sense in important declarations at least from the time of the French and United States revolutions, is controversial for a range of different reasons. We know that in history the notion has not always been a term of approbation and has often evoked fear and been equated with ignorance and the "mob", as is the case with words like the "masses". ${ }^{10}$

That would be an objection emanating from the right, from elitist opposition to the "rabble". But there is also sometimes scepticism about reference to the people from those who purport to speak from the left and see or depict such references as connoting populism. By populism I understand the rhetoric of the popular, relating to what is central to the needs of the masses in words, as opposed to a popular programme, which is not merely rhetoric, but an actual plan of action to remedy what ails the poor and the weak.

The left opposition that the Charter encountered was primarily based on "the popular", including all classes suffering oppression and not putting as much weight as specific sections of the left considered desirable - on the working class.

\section{The Freedom Charter as part of a continuous journey}

When we say that full humanity has been recovered, it does not mean that there is an element of finality in what it is conceived to be, or that it is secured for all time. This is so in the sense that the meaning of recovering humanity may be enriched, that the notion of full humanity may become more expansive, but also there could well be fresh attacks on that humanity, as may be witnessed in the undermining of rights in South Africa today. ${ }^{11}$

\footnotetext{
${ }^{10} \mathrm{R}$. Williams, Culture and Society, 1780-1950 [with new introduction] (Columbia University Press, New York, 1983), pp 296-300; G. Rudé, The Crowd in History, 17301848 (John Wiley, New York, 1964), pp 6-9; M. Canovan, The People (Polity Press, Cambridge, 2005), pp 68-69.

${ }^{11}$ R. Suttner, Recovering Democracy in South Africa (Jacana, Auckland Park, Johannesburg, 2015).
} 
The first interpretative question is who are "the people" who should govern (and immediately following and considered below, how are they to govern)? Referring to the notion of "the people" was not merely a work of rhetoric but a result of changed political conditions and notions of political subjectivity. Invoking "the people" followed a long process of political development, particularly in relation to African political self-assertion.

The self-identification as "the people" did not happen in the first engagements between black and white. In South Africa, the notion of and self-identification as "the people" had taken a long time to enter African political discourse and practice, especially in the development of African involvement in politics, with limited entry of a Christian, western-educated stratum in the nineteenth-century Cape, claiming British (not yet African or South African or popular) subjectivity for themselves. ${ }^{12}$

My understanding of "subjectivity" connotes both African subjection under colonialism and apartheid, and African subject formation, subjectivity, in the sense of self-assertion and agency, emerging in distinct and often contested ways. The form and character of subjectivity changes over time, partly for reasons that the subject determines semi-autonomously but is also substantially conditioned by the changing terms of subjection. The forms of self-representation and content claimed for African political subjectivity has changed under colonialism, apartheid and representative democracy achieved after 1994.

Prior to and during conquest, the native peoples were often conceived outside the bounds of humanity and as occupying terra nullius. Conquest without incorporation led to elaboration of concepts of "civilised" and "uncivilised" people, only the former being entitled to rights. Insofar as some Africans were able to make this claim, with the development of the Cape non-racial franchise, it led to a distantiation of the elite stratum from those who did not qualify and who were often referred to through terminology like "the raw native in the kraal".

In these early years of political activity in the nineteenth century (and also for some decades into the twentieth century) petitioning the Crown or the representative of the Crown in South Africa was the preferred method of raising political grievances amongst the emerging political leadership. But there were also more militant Africanist strains in the appearance of breakaway "Ethiopian churches" from the 1880s. Despite their militancy, the Africanist strains often coexisted with loyalty to the Crown and many of the leaders of the Ethiopian churches were involved with the

${ }^{12} \mathrm{~S}$. Trapido, “'The Friends of the Natives': Merchants, Peasants and the Political and Ideological Structure of Liberalism in the Cape, 1854-1910", in S. Marks and A. Atmore (eds), Economy and Society in Pre-Industrial South Africa (Longman, London, 1980), pp 247-74; R. Suttner, "African Nationalism", in P. Vale, L. Hamilton and E.H. Prinsloo (eds), Intellectual Traditions in South Africa (UKZN Press, Pietermaritzburg, 2014), pp 121-145. 
precursors to and in the formation of the South African Native National Congress (SANNC) later to become the ANC. ${ }^{13}$

In the twentieth century, following the formation of the SANNC, petitioning to be recognised as British subjects (with concomitant rights under the King/Queen) continued. But other movements outside the ANC, notably the Garveyites and the Industrial and Commercial Workers Union (ICU) were often more radical and massbased than the ANC. ${ }^{14}$

Following earlier human rights documents, the ANC developed its "African claims" in 1943 in response to the Atlantic Charter, for the first time claiming universal suffrage and equal citizenship. This was the work of a group of leading intellectuals, not deriving from mass organisation and participation, as was the case with the Freedom Charter. ${ }^{15}$

Then there was the emergence of the Africanist vision of the ANC Youth League (ANCYL), also in the 1940s, tending to refer to South Africa as a country for Africans only. The Africanist orientation was by no means uniform and not necessarily in conflict with the more universalist message of the ANC. ${ }^{16}$ But the narrow exclusivist version would be in the forefront at the time of the PAC split in the late 1950s. ${ }^{17}$

The Freedom Charter draws on all these earlier developments but speaks of "the people" as meaning all South Africans, black and white. In so doing it puts a distance between itself and some, but not all of the Africanist tendencies, those that held that South Africa belonged to Africans alone. Thus Anton Lembede, the first president of

${ }^{13}$ A. Odendaal, The Founders: The Origins of the ANC and the Struggle for Democracy in South Africa (Jacana, Auckland Park, Johannesburg, 2012), pp 156, 200-218; Suttner, "African Nationalism", pp 127-128.

${ }^{14} \mathrm{H}$. Bradford, A Taste of Freedom: The ICU in Rural South Africa, 1924-1930 (Ravan Press, Johannesburg, 1987); J.T. Campbell, Songs of Zion (Oxford University Press, London, 1998); R.T. Vinson, The Americans are Coming! Dreams of African American Liberation in Segregationist South Africa (Ohio University Press, Athens: Ohio, 2012). Sylvia Neame's monumental three-volume study on the Congress movement has only just been published and consequently I have not been able to make a proper study of its 1600 pages. It does appear that it will entail considerable revision of current historiography of the ANC, including engaging with her contention that the ICU should be considered as part of the "Congress Movement", organisationally distinct but in fact a "wing of the ANC itself" or referred to at times by ICU leaders as the "industrial wing" of the ANC in this period. See S. Neame, The Congress Movement, 3 Volumes (HSRC Press, Cape Town, 2015), Volume 1, pp xv, xvi.

15 P. Walshe, The Rise of African Nationalism in South Africa (C. Hurst, London, 1970), pp 271281; T. Lodge, Black Politics in South Africa since 1945 (Ravan Press, Johannesburg, 1983), p 23; K. Asmal, D. Chidester and C. Lubisi, Legacy of Freedom: The ANC'S Human Rights Tradition (Jonathan Ball, Johannesburg, 2005).

${ }^{16}$ R. Suttner, "Understanding Non-racialism as an Emancipatory Concept in South Africa Today", Theoria, 59, pp 35-36; Suttner, "African Nationalism", pp 127-128 and 138-139.

17 G.M. Gerhart, Black Power in South Africa (University of California Press, Berkeley, Los Angeles, 1978). 
the ANC Youth League had challenged the rights of all to be in South Africa as equal citizens, saying: "Africans are the natives of Africa, and they have inhabited Africa, their Motherland, from times immemorial; Africa belongs to them. Africans are one."18

The approach of the Charter was in line with the universalist and egalitarian "African claims". In contrast with earlier tendencies, it is also obviously a claim to South African not British political subjectivity. Insofar as Africanism placed weight on the cultural legacies of African history, the Charter also honours these in its references to culture. Indeed, this was emphasised much earlier by one of the founders of the SANNC/ANC, Pixley ka Isaka Seme. ${ }^{19}$

\section{The Freedom Charter and popular politics of the 1950s}

The Congress of the People campaign, which led to the adoption of the Charter, was part of broader mass mobilisation and organisation that characterised the 1950s, a period of what one may call popular democratic activity or popular nationalism or at any rate, mass popular action. It constituted a break in ANC politics, which had until then been mainly but not exclusively, legal, constitutional and without a mass base. This can be exaggerated, for the early period had not been without significant, albeit sporadic mass activity. Limb, Roux and others demonstrate that there were mass manifestations at an earlier phase, notably a pass defiance campaign in $1919 .{ }^{20}$

In the 1950s the ANC and its allies in what was called the Congress Alliance implemented the Programme of Action deriving from the ANCYL at its formation in 1944 and adopted with some modifications by the ANC as a whole in 1949.21 This led to the Defiance Campaign in 1952, which for the first time turned the ANC into a mass movement. In that period, ANC membership rose to 100000 though those numbers were not sustained in the years that followed. ${ }^{22}$ The earlier activities of the ANC were generally law abiding. Initiating large-scale defiance constituted an embryonic severing of the notion of allegiance to the authority of the South African state. While there had been defiance in 1919 it coexisted with expressions of allegiance to the Crown. ${ }^{23}$

\footnotetext{
${ }^{18}$ See Gerhart, Black Power, p 60.

19 'Document 22: 'The Regeneration of Africa', Speech by Pixley ka Isaka Seme, Columbia University, New York City, April 5 1906", in S. Johns (ed.), From Protest to Challenge: A Documentary History of African Politics in South Africa, 1882-1990, Volume 1, Protest and Hope, 1882-1934, Revised and updated by G.M. Gerhart and S. Johns (eds.) (Jacana Media, Auckland Park, Johannesburg: 2014), pp 155-158.

${ }^{20}$ P. Limb, The ANC's Early Years (UNISA Press, Pretoria, 2010), pp 174-182; E. Roux, Time Longer than Rope, 2nd edition (University of Wisconsin Press, Madison, 1964) pp 117-121. See also Suttner, "African Nationalism", pp 130-134.

${ }^{21}$ See Neame's complex interpretation of the process of ownership of the programme by the ANC "mother body", in Neame, The Congress Movement, Volume 3, pp 272-296.

22 Walshe, The Rise of African Nationalism, pp 402-403 and more generally on the period, see Lodge, Black Politics.

${ }^{23}$ Suttner, "African Nationalism", pp 130-132; R. Suttner, “The African National Congress
} 
Claiming that allegiance was owed to the British Crown was in itself subversive insofar as the legal authority in South Africa was the Union government. This mischievous intent is found in the wording of some petitions to the King over the Natives' Land Act of $1913 .^{24}$

The notion of "the people" in the 1950s and in the Charter referred not only to the African masses but signified all South Africans. And this period until around 1965 was not only a popular, multiracial or as it came to be called, non-racial movement or nationalism, it was also multi-class in character. It rallied all who suffered under apartheid (as well as democratic whites), who would benefit from or feel a real sense of security and belonging with the creation of a democratic state.

This may be the only period in the century-long existence of the ANC that it was hegemonic as an organisation inside the country. In saying this, a distinction is made between the ANC as an organisation and an ANC-led government. These are not the same thing, certainly in terms of the activities of the members, even though there is a convention to refer to the present government as the "ANC government". It is significant that this hegemony coincided with the emergence of popular subjectivity, that is, the notion of the masses as actors in determining their own lives and future. ${ }^{25}$

In summary, the notion of "the people" that was hegemonic at this time comprised all South Africans, that is, coming from all population groups and classes and strata but also insofar as the ANC was the leading force, this was the only period in its history that it occupied that place. It is true that underground units were often in contact with local organisations and activists in the 1980s but that link was not one where the local organisations acted directly on behalf of the ANC. Likewise while the exiled leadership often made calls for mass activity that were in line with the needs of the time (in the sense of being realisable and having considerable impact), their presence was not through an organic link but a vicarious one in that the ANC did not act directly in its own name.

This is to contradict Gerhart and Glaser's statement that the influence of the ANC in exile was often "marginal". ${ }^{26}$ Lusaka did not "run" opposition to apartheid inside the country, but there is plenty of oral and written evidence to the effect that large numbers of UDF leaders and activists saw themselves as carrying out the intentions of the ANC. Much published work refers to activists secretly listening nightly to the ANC's Radio Freedom and carefully studying the organisation's January 8 anniversary

Centenary: A Long and Difficult Journey", International Affairs, 88, 2012, pp 724-725.

${ }^{24}$ Suttner, "The African National Congress Centenary", pp 721-722, citing evidence in "Document 29: An Appeal to the Imperial Parliament and Public of Great Britain, Petition from the South African Native National Congress, June 1914", in Johns (ed.), From Protest to Challenge, Volume 1, pp 182-187.

${ }^{25}$ Suttner, "African Nationalism", p 138.

${ }^{26}$ Gerhart and Glaser, Protest to Challenge, Volume 6, p 120. 
statement. That is why when the ANC declared a particular year in honour of youth or women or some other sector, it would be followed by a proliferation of such organisations inside the country in the year that followed. ${ }^{27}$

\section{What did it mean to say that the people "shall govern!"?}

What did "govern" mean, or what meaning should we give to that word today? What do we understand to be the role of "the people", if they are to govern? This is of course part of a broader debate in democratic history and theory. ${ }^{28}$

At one point this may have seemed obvious, and during the 1950s and specifically at the time of the Charter it was taken to mean one "man (now person) one vote" for the central parliament. Chief Albert Luthuli notes:

There was no longer any doubt in our mind that without the vote we are helpless. Without the vote there is no way for us to realise ourselves in our own land, or even to be heard. Without the vote our future would be that decreed by a minority of whites, as our past has been. ${ }^{29}$

Or as Nelson Mandela put it on many occasions, "We demand universal suffrage",30 or before the Freedom Charter was adopted, "The democratic principle is 'one adult, one vote'". ${ }^{31}$ Seen as a crucial demand, there were songs at the time of the Freedom Charter in the 1950s that conveyed this.

In 1985, I interviewed the late Dorothy Nyembe - who spent 18 years in prison and had been mentored by Chief Albert Luthuli - she sat on the grass at Phoenix settlement outside Durban, which was originally established by Mahatma Gandhi in 1904, and described her work in gathering demands for the Freedom Charter. She said: "All the demands of the Charter point straight to parliament." She then sang:

Chief Luthuli, Dr Naicker (three times)

${ }^{27}$ Much of this is recorded in the documentation of Gerhart and Glaser, Protest to Challenge, Volume 6 itself. But see also R. Suttner, The ANC Underground in South Africa (Jacana Media, Auckland Park, Johannesburg, 2008), pp 68-69 and 162-164 and interviews cited there. See also H. Macmillan, The Lusaka Years 1963 to 1994: The ANC in Exile in Zambia (Jacana Media, Auckland Park, 2013), p 112.

${ }^{28}$ See, for example, C. Ake, The Feasibility of Democracy in Africa (Council for the Development of Social Science Research in Africa, Dakar, 2000), pp 6-32; Arblaster, Democracy; D. Beetham, Democracy and Human Rights (Polity Press, Cambridge, 2000); M. Saward, Democracy (Polity Press, Cambridge, 2003).

${ }^{29}$ A. Luthuli, Let My People Go (Tafelberg, Houghton, Johannesburg, 2006 [1962]), p 101.

${ }^{30}$ Mandela's Treason Trial Evidence, "Document 62, Testimony in R. $v$ Adams and others, Pretoria, March to October 1960", in Karis and Gerhart (eds), From Protest to Challenge, Volume 3, p 548.

${ }^{31}$ N. Mandela "The Shifting Sands of Illusion", in N. Mandela, The Struggle is My Life, (International Defence and Aid Fund, London, 1986), p 43, originally written in 1953. 
Yibona "bonsimel" epalamende

These will represent us in parliament.

Dr Dadoo umhol'wethu (three times)

Dr Dadoo is our leader

Uyena ozosihol' epalamende

Will lead us in parliament

Dr Dadoo umhol' wethu (three times)

Dr Dadoo our leader

Uyena ozosihol' sisepalamende

He's the one to lead us in parliament. ${ }^{32}$

Chief Albert Luthuli was the ANC president from 1952 until his death in 1967, Dr Monty Naicker was the Natal Indian Congress leader from the 1940s and Dr Yusuf Dadoo was head of the Transvaal Indian Congress from the 1940s and later South African Communist Party chairperson until his death in 1983.

It is significant that this song joins African and Indian leaders, given that it was only a short while after the 1949 African/Indian conflict in the then Natal that saw the loss of many lives. This is a tribute to the work of Luthuli and Naicker, in particular, in building non-racialism in the province. But the Indian Congress relationship with the ANC, and the example of the Indian Passive Resistance Campaign of 1946-8, were also crucial in developing the ANC and its allies' mass character. ${ }^{33}$

\section{Representative democracy not the only meaning of the people "shall govern": the "popular power" period}

The process of government would be realised, according to the thinking and songs of the time when the Charter was adopted, by electing leaders to govern. In the context of South Africa, with centuries of racist rule, that represented a qualitatively significant change which was in fact realised in 1994. But that has not been and need not be the only meaning of the terms "The People Shall Govern", as we shall see in the political practices of the 1980 s.

In the period that followed adoption of the Charter, with the banning of the ANC and Pan Africanist Congress (PAC) in 1960, there was a political vacuum at a public level, filled by the assertive and creative emergence of the Black Consciousness Movement and the ambivalent rise of Inkatha. While there was an ANC presence, it could not be overt.

\footnotetext{
32 Suttner and Cronin, 30 Years, pp 252-253. The isiZulu version in the later Suttner and Cronin, 50 Years, is not used because there are printing errors.

${ }^{33}$ See Neame, The Congress Movement, Volume 3, pp 233-239.
} 
In the period after the 1976 uprising the main beneficiaries were the ANC and its allies. Not only were many youths absorbed into the ANC in exile but inside the country a range of organisations covering youth, women, community based organisations known as civics, trade unions and others emerged from the late 1970s, manifesting broad support for the ANC. Because of its illegal status this allegiance was not usually directly stated but demonstrated by reference to the Freedom Charter and other emblematic expressions of the Congress movement. There was also emergence of a range of community media (most of which, incidentally, have disappeared in contemporary South Africa). ${ }^{34}$ The expressions of allegiance to the ANC grew ever bolder with the hoisting of the organisation's flag at funerals and other events.

In 1983 this upsurge took broad organised form with the establishment of the United Democratic Front (UDF), an umbrella organisation representing some 600 organisations and over 2 million members. ${ }^{35}$ As the front developed its aims broadened and it became a direct challenge to the state, in particular where its affiliates, in line with an exhortation from the ANC, made significant parts of South Africa "ungovernable" and apartheid "unworkable". ${ }^{36}$ The ANC and many of the leaders in the country believed that ungovernability was not desirable as a permanent state of affairs and hence, made the call to establish "elementary organs of popular power", partly to fill the vacuum in local governance but also to heighten the resistance. ${ }^{37}$

The democratic significance of the UDF period is often seen as the emphasis on accountability, leaders acting on a mandate and reporting back, features that are akin to how or influenced by the way in which the emerging unions generally operated, and pure notions of representative democracy where a parliamentarian supposedly reports to his or her constituency. That is a very important feature, which is obviously very significant in the context of contemporary parliamentary democracy and problems of accountability. But the democratic contribution of the UDF went beyond accountability.

\footnotetext{
${ }^{34}$ See I. van Kessel, Beyond Our Wildest Dreams: The United Democratic Front and the Transformation of South Africa (University of Virginia Press, London, 2000) on the grassroots newspaper published in the then Cape province in this period.

${ }^{35}$ See, inter alia, J. Seekings, The UDF: A History of the United Democratic Front in South Africa, 1983-1991 (David Philip, Cape Town, 2000); Van Kessel, Beyond Our Wildest Dreams; T. Lodge, "Rebellion: The Turning of the Tide", in T. Lodge, B. Nasson, S. Mufson, K. Shubane and N. Sithole (eds), All, Here and Now: In South Africa in the 1980s (David Philip, Cape Town, 1991), pp 23-141; R. Suttner, "The UDF Period and its Meaning for Contemporary South Africa: Review Article", Journal of Southern African Studies, 30, 3, 2004, pp 691-702; S. Mufson, Fighting Years (Beacon Press, Boston, 1990); M. Neocosmos, "From People's Politics to State Politics: Aspects of National Liberation in South Africa", in A. Olukoshi and L. Laakso (eds), Politics of Opposition in Contemporary Africa (Nordic Africa Institute, Uppsala, 1998), pp 195-241.

36 0. Tambo, "Make South Africa Ungovernable: Broadcast on Radio Freedom, 10 October 1984", at http://www.anc.org.za/show.php?id=4457, accessed 24 August 2015

37 Z. Sisulu, "People's Education for People’s Power", Issue: A Journal of Opinion, 15, 1987, pp 18-29.
} 
In the 1980s the understanding of "The People Shall Govern" came to embrace an enhanced interpretation, to take on a broader meaning in the light of the popular power period. While this was an uneven experience, in that it also included some situations of abuse, it nevertheless embraced important phases and spaces where people took direct control in deciding how some matters should be determined in their lives. ${ }^{38}$

One of the notable features was in the area of popular justice, where apartheid police and structures were driven out of many communities and people took control of their own destinies at a local level. They formed area and street committees and these helped control crime and resolve disputes in streets, blocks and at other levels. In other places they organised crèches, people's parks, cooperatives and other enterprises. ${ }^{39}$ Despite problematic features that emerged mainly when experienced leaders were arrested, the period represented a new development in popular democratic resistance and claims. ${ }^{40}$

In some cases actors self-consciously interpreted what they did in relation to the Freedom Charter. In practising popular power, Uitenhage community leader Weza Made specifically explained his actions in establishing local level committees as comprising the implementation of the first clause of the Freedom Charter. The period may also have extended the practice substantially:

Generally, ja, I can say the community is the main source of power, because the state has really lost the control over the people. He has no power over the people in terms of controlling them. This is why the people have formed these area committees, so that they can try to control themselves. What has been preached in the past about the Freedom Charter, even now we are trying to do that practically.

Q: Do the people know the Freedom Charter quite well in the townships of Uitenhage?

A: They know the Freedom Charter, but especially the first clause, "The People Shall Govern!"41

This meaning given to the words "The People Shall Govern", in the "people's power" period accords with the original meaning of the word democracy, as defined by

\footnotetext{
${ }^{38}$ R. Suttner, "Popular Justice in South Africa Today", Unpublished paper presented to a seminar of the Sociology Department, University of the Witwatersrand, Johannesburg, 5 May 1986. See also Neocosmos, "From People's Politics to State Politics"; and Mufson, Fighting Years.

${ }^{39}$ Interviews held with Weza Made of Uitenhage, Titus Mafolo of Atteridgeville and Gugile Nkwinti of Port Alfred, all conducted in Johannesburg in 1986. Exact dates cannot be provided because the author was detained during the State of Emergency from 1986 to 1988 and some of his records were lost. See also Suttner, "Popular Justice in South Africa Today"; Suttner, "The UDF Period"; and Mufson, Fighting Years.

40 Neocosmos, "From People's Politics to State Politics".

${ }^{41}$ Interview conducted by author, Johannesburg, 1986.
} 
Aristotle, that the people governed directly, a notion that he found deeply disturbing. 42

Many who were involved in these struggles in the 1980s envisaged continuing popular involvement in politics and that their role, as members of communities, would not be reduced to periodic elections of leaders for parliament. Thus Murphy Morobe, a UDF leader, wrote in 1987:

The creation of democratic means is for us as important as having democratic goals as our objective. Too often models of a future democratic South Africa are put forward which bear no relation to existing organisations, practices and traditions of political struggle in this country. What is possible in the future depends on what we are able to create and sustain now. A democratic South Africa will not be fashioned only after transference of political power to the majority has taken place, nor will it be drawn up according to blueprints and plans that are the products of conferences and seminars. The creation of a democratic South Africa can only become a reality with the participation of millions of South Africans in the process - a process which has already begun in the townships, factories and schools of our land. ... Our democratic aim ... is control over every aspect of our lives, and not just the right (important as it is) to vote for a central government every four to five years. ... When we say that the people shall govern, we mean at all levels and in all spheres, and we demand that there be real, effective control on a daily basis. ${ }^{43}$

\section{Theoretical implications of popular power in relation to interpreting the Charter}

This understanding of democracy raises a number of issues whose theoretical implications go beyond the moment of popular power. In the first place, this was a time where there was an overwhelming emphasis on insurrectionism, resulting from the intransigence of the apartheid regime and the build up of forces of resistance, willing to give their lives in armed action to overthrow that state. But notions of insurrectionism focus on a decisive moment of "seizure of power". There is a tendency to downplay the significance of what can be done in the interim that does not immediately feed into taking the "citadels" of power. Insofar as people were governing, albeit in a limited way, in the "here and now" of their lives, it was a qualification of the notion of postponement, waiting for the decisive moment, implied in insurrection.

It meant that democratic gains could be made prior to "seizure" and had implications for the relationship between reform and revolution. It suggested that people could do things that represented their democratic self-empowerment prior to the moment when the people governed in the sense of exercising universal suffrage, and their representatives forming a government. While this may not have

${ }^{42}$ Aristotle, The Politics, translated by J.A. Sinclair (Penguin, Harmondsworth, 1962), p 155. See also the discussion in Ake, Feasibility of Democracy, pp 7-9.

43 M. Morobe, "Towards a People's Democracy: The UDF View", Review of African Political Economy, 14, 1987, p 82. 
been adequately integrated into the ANC/SACP/UDF political theories of the time, it was in fact part of the daily practice of the trade union movement, some of whom were also engaged in insurrectionary activities.

It was also a departure from instrumentalist notions, where democracy was seen as a means to an end whereby state power was the fortress that had to be conquered in order to wield it, as if it were a thing, in support of the needs of one or other class or coalition of classes. ${ }^{44}$ People were to be self-empowered in a range of locations, on an ongoing basis, in addition to what may have been done through the central state.

\section{Crushing popular power}

But the state was determined to crush this rising, that comprised an amplified danger insofar as it went beyond sustained resistance and also put in place alternative governance systems, contesting the reach of state power, albeit at lower levels of the political order. In the words of the minister of Law and Order, Mr Louis le Grange: "Our enemies cannot be allowed to create the impression that they are capable of maintaining their own administration. The State's power and institutions must be protected and maintained." 45

Over 30000 people were arrested in the second State of Emergency of the 1980s, running from June 1986 until February 1990. Many of the popular structures collapsed or were taken over by hooligans (sometimes known as "comtsotsis" a word combining "comrade" and the seSotho slang word for thugs or gangsters, "tsotsis"), due to the arrest of more mature cadres. This absence of older cadres was one of the reasons for the widespread abuse that occurred.

In some areas, however, where people who were outside the range of the official UDF structures, in some bantustans for example, structures had been established and some of these did survive the state onslaught because the conditions of their operation had in any case been semi-legal from the outset. Nomboniso Gasa remarks:

All anti-apartheid organisations were taken as banned and any activity that was part of the struggle we knew were not allowed by the state. However people established networks that linked them to the larger movement some had direct links with the UDF or MK[46] and others did not have such links. ${ }^{47}$

\footnotetext{
${ }^{44}$ See N. Poulantzas, State, Power, Socialism (Verso Books, London and New York, 2000), pp 257-258.

45 The Citizen, 19 February 1986.

${ }^{46}$ The abbreviation for Umkhonto we Sizwe, the ANC's armed wing.

${ }^{47}$ Personal communication from N. Gasa, a schoolgirl in the former Transkei during the 1980s, 23 July 2015.
} 


\section{The disintegration of much of the popular manifestations and emergence of the Mass Democratic Movement (MDM)}

In the absence of the most visible organisations directly connected with the people, the MDM emerged in 1988 to speak on their behalf - as their representative. The MDM, combining the Congress of South African Trade Unions (COSATU) and the South African Council of Churches (SACC), advanced a powerful liberatory message. But, although often equated with the UDF, it was leadership without the direct, organic contact with large sections of the constituency it represented, that the UDF had possessed. The unions had such links, but they were only one element of this. The nexus between organisations and their leaders in the townships was generally severed. ${ }^{48}$

\section{Negotiations and the popular role.}

This severing of the glue which linked people on the ground and those who had been delegated to carry out tasks on their behalf, intensified. In the negotiation period leaders had discussions, representing the people. While the resultant democratic elections constituted a qualitative advance, we need to note that this was a period that again emphasised the representative character of democratic practices, and that the direct popular role was limited. Periodic reports on complicated and technical issues in negotiations were not the same or similar to the popular engagement that people had practised in the 1980s. It was one element of a phase where a selfempowered people became one who had others act on their behalf, on the basis of their representatives securing democratic gains.

This is not to question whether it was possible to conduct negotiations in another way, but indicating that this was part of a process of displacing the popular by the representative. There was no explicit decision to demobilise the masses but it happened. For the popular subject to persist would have required some thought and discussion on how it could be integrated into or coexist with constitutional structures that were to be negotiated. That never happened, insofar as neither the UDF nor the ANC leadership contested the trajectory that was followed. It should be noted that the UDF tended to view itself as a "B team", standing in for the ANC, the "A team". When the ANC leadership returned from exile and Robben Island the UDF dissolved itself. 49

\section{Can representative democracy coexist with popular democracy?}

Let us not underestimate the achievement that representative democracy meant a great victory for the people of South Africa against apartheid. But having the vote did not mean that the people would be directly present in the arenas that would

${ }^{48}$ Neocosmos, “From People's Politics to State Politics", p 206; Lodge, "Rebellion”, p 114.

${ }^{49}$ See Suttner, "African Nationalism", pp 141-142; and Suttner, "The UDF period", pp 699700 , where this UDF self-evaluation is contested. 
determine key elements of their lives. This must be qualified in that there are now spaces for interested parties and communities to make representations that have emerged (see below).

In the main, however, through exercising their vote they were now to be represented by what some may have considered or depicted as a "people's movement" and then a "people's government".

In the constitutional system resulting from negotiations, with the emphasis on the vote for legislative chambers, for all intents and purposes popular direct involvement or popular subjectivity was generally displaced.

What needs to be asked, in reflecting on the Freedom Charter today and in particular on its popular character, is whether the political role of the public apart from periodic voting, is intended to be primarily that of observers and if not, how their role is to be manifested.

\section{Interrogating the meaning of representation}

Before briefly considering whether it is possible to recapture the popular character manifested in the politics of the 1980s it is important to interrogate the question of representative government and the meaning of "representation" as a concept. This is especially necessary because the history of representative government's introduction in the United States Constitution was part of a process of displacing the original meaning of democracy that of popular, direct action..$^{50}$ That is why Claude Ake refers to representative democracy as "a contradiction in terms". ${ }^{51}$ In order to probe this, we need to examine some of the potential meanings of representation.

When Dorothy Nyembe and others sang of being represented by their revered leaders they saw these leadership figures embodying a close relationship with the communities they were from or who were their support base. They saw them embracing the aspirations of the oppressed. They understood there to be a connection between themselves and those who would go to parliament, a bond that would not be broken once these people entered the law-making chambers to represent them. They trusted them and had no reason to doubt that the trust would be respected.

But the word "representation" can bear more than one meaning and be more or less conducive to re-presentation of the views and interests of the people who have voted. It can mean a form of representation where the representative need/does not consider the voter the moment $\mathrm{s} /$ he enters parliament or that constituency may be very much present in parliament. The notion of bearing no accountability to the constituency was classically expressed by Edmund Burke to the voters of Bristol in

${ }^{50}$ Ake, The Feasibility of Democracy, pp 6-12.

${ }^{51}$ Ake, The Feasibility of Democracy, p 11. 
1774: "Your representative owes you not his industry only, but his judgment; and he betrays, instead of serving you, if he sacrifices it to your opinion." 52

In contrast, representation, John Hoffman and Paul Graham argue, "involves empathy - the capacity to put yourself in the position of another - and while it is impossible to actually be another person, it is necessary to imagine what it is like to be another". ${ }^{53}$

In this understanding, representation accords with that of connectedness and solidarity, acting with compassion and passion in relation to those who need one's assistance or whom one has the capacity to assist, themes found repeatedly in texts of feminist and other forms of liberation theology. 54

Furthermore, Hoffman and Graham stress that in this relationship, accountability is central and they also link it to parliament itself being representative of the various components of the population:

Accountability is "the other side" of representation: one without the other descends into either impracticality or elitism. The notion of empathy points to the need for a link between representatives and constituents. Unless representatives are in some sense a reflection of the population at large, it is difficult to see how empathy can take place. Women who have experienced oppression by men (or partners) at first hand, are more likely to have insight into the problems women face than men who - however sympathetic they may be - may have never been the recipients of that particular form of discrimination. The same is true of ethnic and sexual minorities, etc. To have experienced humiliation directly as a disabled person, makes one far more sensitive to questions of disability. We need a form of representation that is sensitive to the particular identities and problems of those they represent. ${ }^{55}$

For those who argue for direct democracy, Hoffman and Graham caution that participation need not mean that it can only happen through direct involvement in political processes. "Direct involvement needs to be linked to representation, and it is worth noting that in the ancient Greek polis - often held up as an example of direct democracy - the assembly elected an executive council. ${ }^{56}$

52 E. Burke, "Statement to the Electorate of Bristol" in 1774, at http://presspubs.uchicago.edu/founders/documents/v1ch13s7.html, accessed 29 July 2015.

$53 \mathrm{~J}$. Hoffman and P. Graham, Introduction to Political Theory, 2 ed. (Pearson Longman, London, 2009) p 110.

${ }^{54}$ See, for example, S. Purvis, “Compassion”, in L.M. Russell and J.S. Clarkson (eds), Dictionary of Feminist Theologies (Westminster John Knox Press, Louisville: Kentucky, 1996), pp 50-51.

55 Hoffman and Graham, Introduction to Political Theory, p 110. Obviously, deriving from a specific section of the population, does not necessarily mean that the representative will further the interest of that group. Many women, on entering a patriarchal parliamentary institution and cabinet, themselves adopt patriarchal modes of operating, little different from the patriarchal men who constructed the institutions that are not women-friendly. Audre Lorde famously wrote: "The Master's Tools will never dismantle the Master's House", in Sister Outsider (Crossing Press, Berkeley, 2007), p 110.

${ }^{56}$ Hoffman and Graham, Introduction to Political Theory, p 110. 


\section{Representation and abuse of trust in contemporary South African politics}

It has been repeatedly noted that trust in the current South African leaders who represent voters in parliament has been abused; they have failed to act according to their oath of office and to hold people, including the president, accountable as well as acting irregularly in a range of other ways. ${ }^{57}$

In so doing the sense of connectedness that may once have existed between the electorate and their representatives has been ruptured or put under severe strain. For the representatives to condone the diversion of funds meant for the poor towards luxurious improvements in the president's homestead comprises an alienation from that which previously bound many of them to their constituency. It signifies that even if their constituency is not conversant with the intricacies of reports and evaluations of the spending on Nkandla, that at an objective level the act of MPs in endorsing such expenditure, which has a negative effect on the poor, runs against the ethos on which their election as public representatives may have been premised.

This raises a delicate and difficult question referred to earlier, and that is whether election "trumps" subsequent conduct, whether democratic election at one point in time means that it confers legitimacy in perpetuity. One would not then be able to enquire into conduct that runs against that democratic expectation in the course of acting as a popular representative. Because the person was democratically elected are we barred from concluding that their conduct no longer bears the authority and legitimacy once conferred?

The argument presented here is that it is valid to assert that legitimacy and authority, even if conferred through the ballot box, is not finally and unconditionally granted. Should representatives conduct themselves in a manner that undermines the basis on which they have been elected, or attacks the interests of those who are their constituency, that authority can be challenged or we may say that their actions are without a mandate or undermine the mandate "to represent" that they were given. ${ }^{58}$

It is important in this context that citizens who wish to recover democracy that has been undermined, clarify precisely what organisational forms are needed and find ways of asserting a political role. This would aim at redirecting what has currently taken a route very different from the democratic development that many had hoped to see.

\footnotetext{
${ }^{57}$ Suttner, Recovering Democracy, pp 20-22, 26-28 and 144-146.

${ }^{58} \mathrm{~A}$ recognition that the Syriza government in Greece found itself acting in a manner that contradicted their electoral mandate over state debt, led to their resignation and the September 2015 elections.
} 


\section{Making public representations to legislatures}

Beyond reliance on public representatives acting with empathy and fulfilling the trust bestowed on them, there are provisions in current South African constitutional law for representations to be made to parliament, that is for communities, community based organisations and other aggrieved parties to represent themselves directly in making presentations to parliamentary committees of various types, to advance their arguments directly on various matters. This was not the case in the apartheid parliament but derives from changes in the rules in the early days of the democratic parliament. 59

There are definitely limits on the value of such processes in that the terms on which the making of representations become possible are decided by parliament and there is often insufficient time for adequate and effective testimony from the public. Equally, the form in which such openings are provided is often highly technical and the communities or community based organisations concerned may not have the expertise to be able to engage adequately on their own, in order to be heard and represent themselves successfully.

Often the necessary resources, financial and relevant skills are present in civil society, in non-governmental organisations (NGOs) and various research institutes. In many cases, such civil society organisations have made important interventions that have helped remedy problems in specific legislation or actions or inaction on the part of government.

Insofar as communities wish to be directly involved in seeking remedies or averting the imposition of injurious legislation, it is difficult to do so where the necessary resources are unavailable. Generally, poor communities have difficulty holding meetings which may entail covering transport costs and often finding a venue, providing refreshments and sometimes accommodation.

In some situations, organs of civil society do work with communities. It becomes important for the development of democracy to ask how the resources of civil society are used, the extent to which and how they are put at the service of the communities and community based organisations where this interrelationship becomes possible. On the one hand, it is unclear to what extent the broad range of aggrieved communities can be assisted given the limits of the resources that are available. But it is not always clear why some are assisted and others not, that is, on what basis some NGOs/institutes with resources make their decisions.

Of particular significance is the extent to which NGOs and other institutes or organisations with resources attempt to involve communities in the process of resolving their problems or making representations, whether steps are taken to

${ }^{59}$ P. de Vos and W. Freedman (eds), South African Constitutional Law in Context (Oxford University Press, Cape Town, 2014), pp 119-122. 
ensure that the communities "own" the process through which a problem may be resolved or an attempt may be made to seek a remedy, with or without success.

It is sometimes the case that the financial resources and technical expertise results in a victory on behalf of communities in situations where communities could be more extensively involved and play a greater role in the process.

What becomes clear in relation to parliament is that the notion of representation may be conceived more or less narrowly and that community action may be a factor that can increase direct popular involvement in matters affecting themselves.

How this can be achieved needs more careful scrutiny than is possible here. All that was attempted was to unpack the notion of representation and displace the notion that "representation" need stand as necessarily opposed to the "popular".

\section{Is there room for direct popular action or direct democracy today?}

While there are openings for popular representations to be made to the government or state in various fora, direct democracy is not encouraged and is not conceived in the conception of popular participation that has been allowed or propagated by the ANC since 1994.

There is, however, nothing illegal in forming social organisations that address community issues without their having to be linked to any organs of state, or they may decide on an ad hoc or a regularised basis to form such linkages with state institutions. Equally, any such movements or organisations that may be formed must conform to the constitution and other laws of the country. That may be so, but we need to ask: what are the conditions that make it possible and viable to establish and sustain such organisations?

Street committees, one of the characteristic features of popular power in the 1980s do exist in some communities, some surviving from that period and some established in recent times. Many of the organisations that have been formed have been established in relation to issues that have a negative effect on community members, in particular their conditions of living.

Nowadays there are a lot of protests, more or less popular in character -what are called "service delivery" protests - around failure to meet basic needs, as laid down in the constitution. They often happen one day and fizzle out the next and then sometimes break out somewhere else. But sustained popular power requires organisation in communities with some stability in the relationships between people. It is hard to achieve that in the dehumanised conditions in which many people now live, repeatedly documented, with sewage flowing in the streets, often without fresh water, etc etc. Even if one accepts the desirability of popular power in this sense of the original meaning of democracy, it will take long to re-create conditions that make 
it possible, although some organisations like the shack dwellers movement Abahlali baseMjondolo, located mainly in KwaZulu-Natal and the Western Cape, appear to maintain their existence despite adverse conditions, including continued repression and very limited support from the NGO sector.

\section{Conclusion}

Let us be clear that any argument for popular democracy should not mean denial of the constitutional gains made since 1994 and the need to defend these. In postapartheid South Africa these need to be consolidated, built on and utilised as far as possible in order to advance people's rights and capabilities. But the popular character of the Freedom Charter, based on the experiences in this country, mainly in the $1980 \mathrm{~s},{ }^{60}$ can also be taken to refer to popular involvement in social and political action outside of institutions that are provided for in the constitution. This does not mean illegal or anti-constitutional action, but activity that is self-empowering in ways that are not necessarily envisaged by, yet are compatible with the constitution.

This conforms to the notion of an "active citizenry", found in contemporary discourse, active and with self-agency within and beyond what is written in the constitution in order to realise people's freedom in ever growing senses. Reference to an active citizenry has a wider appeal than those who may draw inspiration from the 1980s, having some resonance amongst sections of the middle class and business that may come to consider it desirable to build relationships around limited issues that are important for the defence of democracy. This may sometimes be together with organised workers and other sectors that share some commonality around specific issues, sometimes covering a narrow area or broader questions.

In order for action on behalf of communities to be effective it requires similar processes of organisation to those described for popular power. There need to be communities who are able to meet and discuss and formulate their standpoints. This may require resources that they do not have and this again raises the question of the relationship they may have with NGOs and various institutes and foundations that do have resources that can assist them.

If the Freedom Charter is to survive as a living document it ought not to be given a status that is beyond question. It needs to be debated and its various meanings openly contested. That may mean it can be part of the general deliberation that is needed for contemporary democratic life to thrive.

60 The experiences are not exclusively in that period, for there was the mountain court in the Mpondoland uprising in the late 1950s. 